\title{
STUDI EKSPERIMENTAL PERILAKU TEKAN BAJA RINGAN DENGAN VARIASI PROFIL PENAMPANG
}

\author{
RIDHO AIDIL FITRAH ${ }^{1}$, HAZMAL HERMAN ${ }^{2}$ \\ Program Studi Teknik Sipil, Universitas Dharma Andalas ${ }^{1,2}$ \\ ridho.af@unidha.ac.id ${ }^{1}$, hazmalherman@ymail.com²
}

\begin{abstract}
Researches about cold formed steel have significantly rose to determine the appropriate analysis and design. SNI 7971:2013 is Indonesia's code contained about the design of cold formed steel structure. However, there is still issue that concern to design of cold formed steel under compression load. It is buckling failure where local buckling commonly occurred in compression element of cold formed steel because the geometry or section's factor. Every types of cold formed steel's section gave the different type of buckling propagation. Thus, experimental investigation is needed to determine about structural behavior of cold formed steel under compression load especially for the sections where is commonly used in construction, single channel and double channel. Double channel back to back and double channel box were used in this experiment. The experiment investigation did by using the universal testing machine where total 3 specimens, each section one specimen, were tested as the short column. Load versus axial shortening curves were obtained in this experiment and analytically compared with SNI 7971:2013 code, local buckling propagation was observed too. Based on the result, double channel box has significant large value of compression strength and stiffness compared to double channel back to back and single channel. Furthermore,SNI 7971:2013 showed conservative result to predict the compression strength of cold formed steel section.
\end{abstract}

\section{Keywords: Cold Formed Steel, Compression Strength, Buckling Failure}

Abstrak: Penelitian tentang baja ringan sudah sangat meningkat untuk menentukan analisis dan desain yang tepat. Salah satu peraturan di Indonesia tentang desain struktur baja canai dingin atau ringan adalah SNI 7971: 2013. Namun, ada hal yang menjadi fokus perhatian pada baja ringan saat didesain pada elemen tekan. Salah satu tekuk yang terjadi pada elemen tekan baja ringan yaitu tekuk lokal yang disebabkan oleh faktor geometri atau penampang. Setiap penampang baja ringan memberikan bentuk tekuk yang berbeda-beda. Untuk itu perlu dilakukan studi eksperimental tentang perilaku tekan pada beberapa bentuk profil baja ringan kanal $\mathrm{C}$ baik tunggal dan simetris ganda, seperti double channel box dan double channel back to back. Uji tekan akan dilakukan dengan universal testing machine dengan jumlah benda uji sebanyak 3 sampel, 1 sampel untuk masingmasing penampang, sebagai kolom pendek. Hasil pengujian ini adalah berupa kurva beban versus perpendekan yang akan dibandingkan dengan hasil analitik berdasarkan peraturan SNI 7971:2013. Selain itu, propagasi tekuk lokal yang terjadi di masing-masing penampang juga diamati. Berdasarkan hasil pengujian tersebut didapatkan penampang double channel box memiliki nilai beban ultimit dan kekakuan yang signifikan dibandingkan double channel back to back dan single channel. Selanjutnya, perhitungan kapasitas tekan berdasarkan SNI 7971:2013 sangat konservatif.

Keywords: Baja Ringan, Kuat Tekan, Tekuk Lokal

\section{PENDAHULUAN}

Seiring berkembangnya pengetahuan konstruksi saat ini menuntut material memiliki performa yang baik dalam hal efisiensi waktu dan biaya serta kuat dan aman, tidak terkecuali baja ringan. Baja ringan merupakan material konstruksi yang dibentuk melalui proses pabrikasi yang konstitutif dengan membentuk profil baja pada suhu ruang. Material ini memiliki ketebalan dari $0.4 \mathrm{~mm}$ sampai 6.4 $\mathrm{mm}$ sehingga termasuk dalam material tipis (thin walled).

Keunggulan dari material baja ringan ini adalah tegangan lelehnya mendekati $500 \mathrm{MPa}$ sehingga termasuk material yang kuat serta beratnya yang ringan dan mudah didapat di pasaran. Saat ini baja ringan menjadi material yang populer dalam hal penggunaannya di 
dalam konstruksi bangunan terutama seperti kuda-kuda.

Penelitian tentang baja ringan sudah sangat meningkat untuk menentukan analisis dan desain yang tepat. Namun, ada hal yang menjadi fokus perhatian pada baja ringan saat didesain untuk dapat memikul beban tekan yaitu tekuk. Tekuk menjadi sebuah fenomena bagi material konstruksi khususnya pada struktur yang memiliki rasio kelangsingan yang besar dan ketebalan penampang yang tipis. Tekuk merupakan sebuah kegagalan struktur dimana penampang mengalami perubahan bentuk pada saat atau sebelum struktur mencapai kapasitas lelehnya. Hal ini merupakan salah satu kelemahan dari baja ringan. Dua jenis tekuk yang sering terjadi pada baja ringan adalah tekuk lokal dan tekuk global dimana salah satu faktor yang mempengaruhinya adalah faktor geometri atau penampang. Menurut Sandjaya dan Suryoatmono (2018) tekuk lokal merupakan kegagalan yang sering terjadi untuk elemen tekan baja ringan walaupun diberikan pengaku.

Beberapa bentuk penampang baja ringan yang beredar di pasaran adalah penampang kanal dan penampang boks dengan ukuran yang bervariasi dan juga kebutuhan dalam penggunaan konstruksi. Bentuk kanal sering digunakan pada struktur rangka (structural frame). Menurut Ruus dkk (2017) profil kanal yang sama memiliki kapasitas tekan dan perilaku tekuk yang berbeda-beda. Hal ini disebabkan karena modifikasi beberapa profil kanal tersebut. Selanjutnya, menurut Kadir dkk (2013) kapasitas tekan yang dihitung dengan pendekatan langsung penampang double channel memiliki perbedaan yang overestimate namun tetap konservatif untuk digunakan. Tentu saja berdasarkan teori yang sudah dipaparkan sebelumnyapenampangpenampang tersebut memberikan kapasitas dan perilaku tekan yang berbeda-beda. Secara analitis, kapasitas tekan suatu penampang baja ringan dapat dihitung berdasarkan peraturan SNI 7971: 2013 pasal 3.4. Namun, pada hakikatnya perhitungan tegangan tekuk kritis belum sepenuhnya sesuai dengan kebutuhan desain. Banyak parameter-parameter yang perlu ditemukan untuk pendekatan perhitungan yang lebih konservatif.
Berdasarkan latar belakang yang dipaparkan maka perlu dilakukan studi eksperimental berupa uji tekan baja ringan untuk mendapatkan perilaku tekan beberapa penampang baja ringan dengan perhitungan kapasitas tekan dari baja canai dingin berdasarkan peraturan SNI 7971: 2013. Profil baja ringan yang akan diuji adalah profil kanal $\mathrm{C}$ yang beredar di pasaran. Profil tersebut akan disambung menjadi kanal ganda back to back dan boks menggunakan sekrup. Pengujian ini menggunakan universal testing machine. Sehingga, hasil penelitian ini menjadi parameter untuk desain struktur baja ringan khususnya elemen tekan.

\section{METODE PENELITIAN}

Pengujian dilakukan dengan menggunakan alat Universal Testing Machine (UTM) dengan jumlah sampel sebanyak 3 sampel. Propertis material yaitu tegangan leleh $\left(\mathrm{f}_{\mathrm{y}}\right)$ diambil sebesar $550 \mathrm{MPa}$ dan detail penampang baja ringan dapat dilihat seperti pada Tabel 1 dan Gambar 1. Baja ringan yang diuji memiliki ukuran penampang kanal $\mathrm{C} 75$ $\mathrm{mm} \times 35 \mathrm{~mm} \times 0.75 \mathrm{~mm}$. Penampang kanal ganda back to back dan boks disambung menggunakan sekrup. Ketidaksempurnaan bentuk penampang akibat pemotongan sampel diasumsikan tidak memiliki pengaruh dalam pengujian ini.

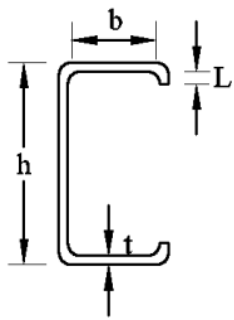

(a)

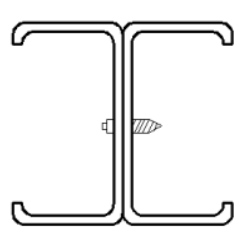

(b)

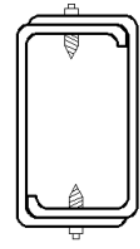

(c)
Gambar 1. Penampang Baja Ringan (a) Single Channel (b) Double Channel Back to Back (c) Double Channel Box

Tabel 1. Detail dan Propertis Penampang Baja Ringan

\begin{tabular}{|c|c|c|c|}
\hline Penampang & $\begin{array}{c}\text { Tinggi } \\
(\mathrm{h}) \\
(\mathrm{mm})\end{array}$ & $\begin{array}{c}\text { Lebar } \\
(\mathrm{b}) \\
(\mathrm{mm})\end{array}$ & $\begin{array}{c}\text { Tebal } \\
(\mathrm{t}) \\
(\mathrm{mm})\end{array}$ \\
\hline $\begin{array}{c}\text { Single } \\
\text { Channel }\end{array}$ & 75 & 35 & 0,75 \\
\hline $\begin{array}{c}\text { D.C Back to } \\
\text { Back }\end{array}$ & 75 & 70 & 0,75 \\
\end{tabular}


Vol. 2 No.1 Januari 2019

http://jurnal.umsb.ac.id/index.php/RANGTEKNIKJOURNAL

\begin{tabular}{|c|c|c|c|}
\hline D.C Box & 75 & 35 & 0,75 \\
& & & 1,5 \\
\hline
\end{tabular}

\begin{tabular}{|c|c|c|c|}
\hline Penampang & $\begin{array}{c}\text { Lip } \\
(\mathrm{L}) \\
(\mathrm{mm})\end{array}$ & $\begin{array}{c}\text { Luas (A) } \\
\left(\mathrm{mm}^{2}\right)\end{array}$ & $\begin{array}{c}\text { Tegangan } \\
\text { Leleh (fy) } \\
(\mathrm{MPa})\end{array}$ \\
\hline $\begin{array}{c}\text { Single } \\
\text { Channel }\end{array}$ & 1,00 & $\pm 110,25$ & 550 \\
\hline $\begin{array}{c}\text { D.C Back to } \\
\text { Back }\end{array}$ & 1,00 & $\pm 220,5$ & 550 \\
\hline D.C Box & 1,00 & $\pm 220,5$ & 550 \\
\hline
\end{tabular}

Panjang masing-masing sampel adalah $300 \mathrm{~mm}$ dan termasuk sebagai kolom pendek (short column) karena rasio kelangsingan elemen tekan kecil dari 50 sehingga perilaku tekan yang dapat diamati pada pengujian ini adalah tekuk lokal. Pengujian menggunakan metode displacement control dengan boundary condition nya adalah semi-rigid. Pengujian akan dihentikan pada saat perpendekan sampel mencapai $20 \mathrm{~mm}$. Hasil dari pengujian ini adalah bentuk kegagalan elemen tekan dan kurva beban-perpendekan. Hasil beban maksimum $\left(\mathrm{P}_{\mathrm{u}}\right)$ pengujian akan dibandingkan dengan secara analitik menggunakan SNI 7971:2013 pasal 3.4.1 (pers.1) dan 3.4.2 (pers.3)

Dimana :

$$
N_{c}=A_{e} \cdot f_{n}
$$

(Pers.1)

$A_{e}=$ Luas efektif saat terjadi tegangan kritis

$f_{n} \quad=$ Tegangan kritis yang ditentukan berdasarkan kelangsingan nondimensi $\left(\lambda_{c}\right)$.

Kelangsingan non-dimensi $\left(\lambda_{c}\right)$ ditentukan dari perbandingan tegangan leleh $\left(f_{y}\right)$ dan tegangan tekuk elastis $\left(\mathrm{f}_{\mathrm{oc}}\right)$.

$$
\begin{aligned}
\lambda_{c} & =\sqrt{\frac{f_{y}}{f_{o c}}} \\
f_{o c} & =\frac{\pi^{2} E}{\left(l_{e} / r\right)^{2}}(\text { Pers.3) }
\end{aligned}
$$

Dimana :

$l_{e}=$ panjang efektif penampang

$r=$ radius girasi penampang utuh

\section{HASIL DAN PEMBAHASAN \\ 1. Uji Tekan Baja Ringan}

Hasil pengujian tekan 3 buah sampel baja ringan dengan variasi bentuk penampang ditampilkan pada Tabel 2. Gambar 2 mengilustrasikan kurva beban versus perpendekan hasil pengujian. Berdasarkan, tabel tersebut didapatkan bahwa beban ultimit penampang D.C Back to Back dan D.C Box lebih besarjika dibandingkan dengansingle channel secara berturut-turutberkisar 51,69\% dan $63,18 \%$. Untuk ketiga penampang tersebut beban ultimit dicapai pada saat perpendekan berkisar $4 \mathrm{~mm}$. Selanjutnya, kekakuan penampang D.C Back to Back dan D.C Box juga lebih besar berkisar 37,62\% dan $67 \%$ secara berturut-turut jika dibandingkan dengan penampang single channel. Sehingga menggabungkan profil baja ringan menjadi kanal ganda dapat meningkatkan beban ultimit dan kekakuan secara signifikan sebagai

\begin{tabular}{|c|c|c|c|c|}
\hline $\begin{array}{c}\text { Penampan } \\
\mathrm{g}\end{array}$ & $\begin{array}{c}\text { Beban } \\
\text { Ultimi } \\
\mathrm{t} \\
(\mathrm{kN})\end{array}$ & $\begin{array}{c}\text { Perpe } \\
\text { n- } \\
\text { dekan } \\
\text { Ultimi } \\
\mathrm{t} \\
(\mathrm{mm})\end{array}$ & $\begin{array}{c}\text { Kekak } \\
\text { uan } \\
(\mathrm{kN} / \mathrm{m} \\
\mathrm{m})\end{array}$ & $\begin{array}{c}\text { Kega } \\
- \\
\text { galan }\end{array}$ \\
\hline $\begin{array}{c}\text { Single } \\
\text { Channel }\end{array}$ & 18.69 & 4.4 & 4,247 & T.L \\
\hline $\begin{array}{c}\text { D.C Back } \\
\text { to Back }\end{array}$ & 28.35 & 4.85 & 5,845 & T.L \\
\hline D.C Box & 30.50 & 4.3 & 7,093 & T.L \\
\hline
\end{tabular}
elemen tekan.

Tabel 2. Hasil Pengujian Tekan Baja Ringan

Note: T.L-Tekuk Lokal

Gambar 2 menjelaskan tentang grafik beban versus perpindahan untuk ketiga sampel. Secara umum pada saat kondisi ultimit tercapai, baja ringan mengalami penurunan beban. Setelah itu terjadi peningkatan beban seiring dengan bertambahnya perpendekan baja ringan. Kegagalan yang terjadi secara umum adalah kegagalan akibat tekuk lokal. 


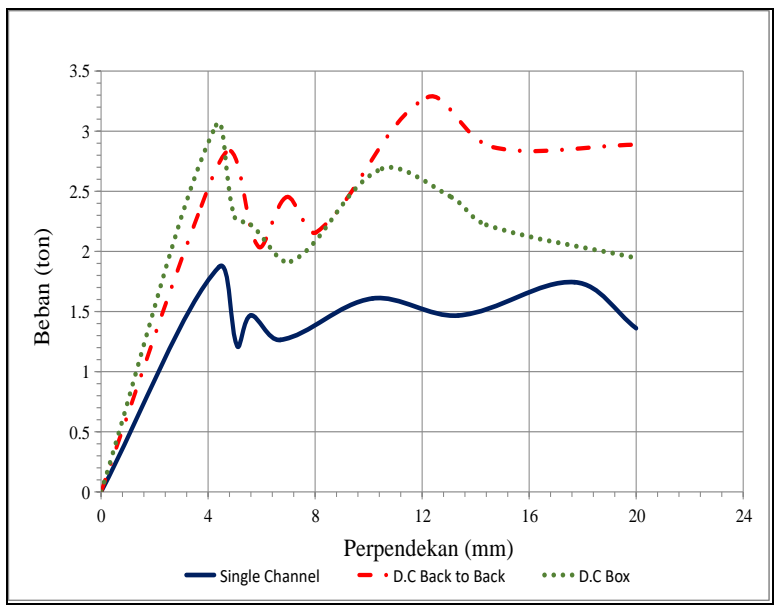

Gambar 2 Kurva Beban Versus Perpendekan Untuk penampang single channel pada Gambar 3. Saat beban ultimit akan tercapai tekuk lokal mulai terjadi pada bagian sayap di bagian kanan dan kiri. Bagian web juga mulai berdeformasi ke arah depan. Saat beban ditingkatkan tekuk mulai terjadi pada bagian bawah sampel dan diikuti dengan tekuk ke bagian dalam pada bagian sayap. Peningkatan kekuatan terjadi akibat adanya peningkatan kekakuan pada bagian yang telah mengalami tekuk. Pada saat perpendekan mencapai batas displacement yaitu $20 \mathrm{~mm}$, bagian sayap telah mengalami robek.

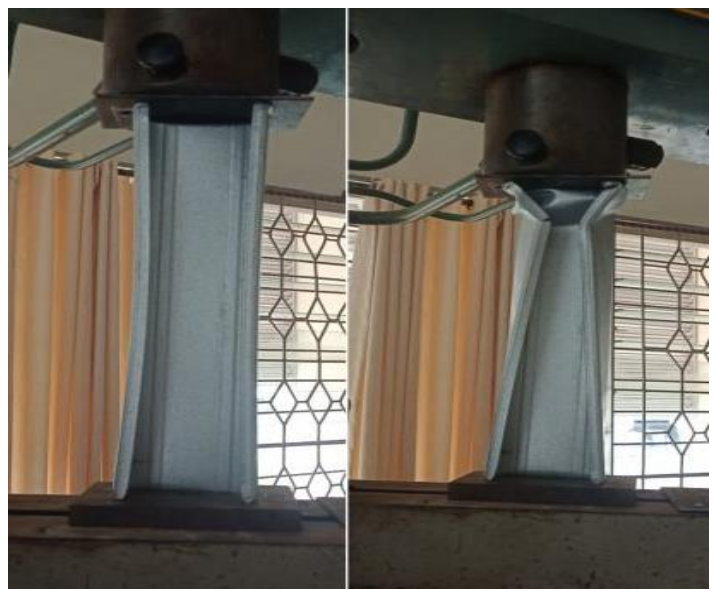

Gambar 3. Kondisi Kegagalan Pada

Penampang Single Channel

Untuk penampang D.C Back to Back pada Gambar 4. Saat beban ultimit akan tercapai tekuk lokal mulai terjadi pada bagian sayap kedua sisi di bagian kanan dan kiri. Bagian web juga mulai berdeformasi ke arah depan dan bagian bawah sampel sudah mulai tertekuk.Saat beban ditingkatkan tekuk pada sayap bagian bawah sampel mulai melebar dan diikuti dengan terpisahnya dua sisi baja ringan.
Peningkatan kekuatan terjadi akibat adanya peningkatan kekuatan oleh sambungan sekrup bagian atas. Saat perpendekan mencapai batas displacement yaitu $20 \mathrm{~mm}$, dua sisi web baja ringan telah terpisah dan sampel memiliki sudut kemiringan.

Untuk penampang D.C Box pada Gambar 5. Saat beban ultimit akan tercapai tekuk lokal mulai terjadi pada sayap terluar bagian tengah di sisi kanan. Hal ini terjadi karena sambungan sekrup tidak dipasang pada daerah tersebut sehingga bagian tersebut adalah bagian terlemah dari penampang baja ringan D.C Box. Saat beban ditingkatkan, bagian web pada sisi bawah mulai tertekuk dan bagian sayap terluar mulai terlihat melebar. Peningkatan kekuatan terjadi akibat adanya tahanan dari bagian sekrup.Pada saat perpendekan mencapai batas displacement yaitu $20 \mathrm{~mm}$, bagian sayap sisi bawah baja ringan sudah mengalami pelebaran tekuk yang sangat besar dan bagian sekrup sudah mengalami kegagalan.

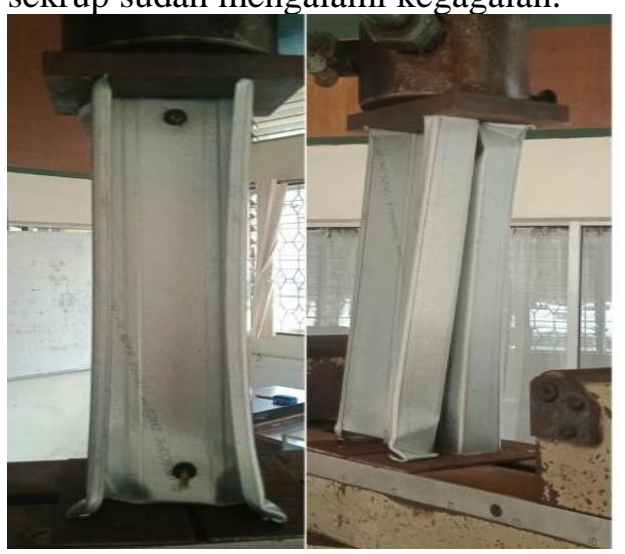

Gambar 4. Kondisi Kegagalan Pada Penampang D.C Back to Back

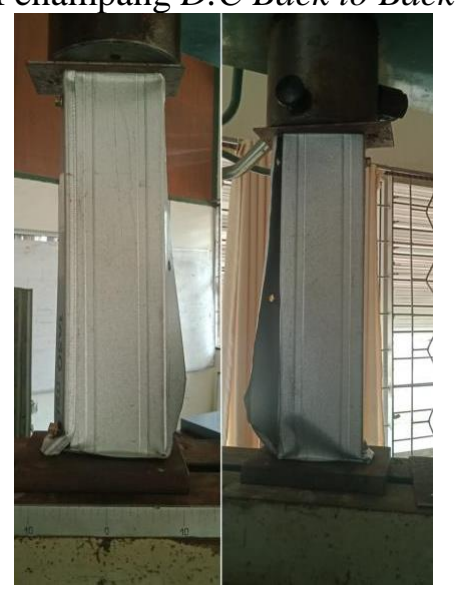

Gambar 5. Kondisi Kegagalan Pada Penampang D.C Box 


\section{Perbandingan SNI 7971:2013 dan Eksperimental}

Data eksperimental digunakan untuk membandingkan ketepatan SNI 7971:2013 dalam memprediksi kuat tekan baja ringan. Perhitungan kapasitas tekan baja ringan mengacu berdasarkan peraturan SNI 7971:2013 pasal 3.4.1 (pers.1) dan pasal 3.4.2. (pers.3)Pada pasal tersebut menjelaskan komponen baja ringan penampang tunggal atau simetris ganda ditekan dengan pembebanan konsentris. Tekuk yang terjadi pada saat pengujian didominasi oleh tekuk lokal sehingga pasal tersebut relevan dengan kondisi eksperimental.

Secara garis besar perhitungan kapasitas tekan untuk kondisi kolom pendek dipengaruhi oleh beberapa parameter seperti luas efektif, tegangan leleh, kelangsingan non-dimensi, dan rasio kelangsingan.

Tabel 3 menunjukkan perbandingan perhitungan kapasitas tekan baja ringan SNI 7971:2013 dan hasil eksperimen. Hasil perbandingan berada di atas 0.75 , berarti perhitungan berdasarkan SNI 7971:2013 pasal 3.4.1 dan 3.42 sangat konservatif dalam memprediksi kapasitas nominal penampang baja ringan simetris tunggal dan ganda.

Tabel 3. Perbandingan Hasil Kapasitas Tekan Berdasarkan SNI dan Eksperimental

\begin{tabular}{|c|c|c|c|}
\hline & $\begin{array}{c}\mathrm{Pu} \\
\text { SNI } \\
7971: 201 \\
3 \\
(\mathrm{kN})\end{array}$ & $\begin{array}{c}\mathrm{Pu}^{*} \\
\text { Eksperi } \\
\text { me-ntal } \\
(\mathrm{kN})\end{array}$ & $\begin{array}{c}\mathrm{Pu} / \\
\mathrm{Pu}^{*}\end{array}$ \\
\hline $\begin{array}{c}\text { Single } \\
\text { Channel }\end{array}$ & 14,75 & 18,69 & 0.789 \\
\hline $\begin{array}{c}\text { D.C Back to } \\
\text { Back }\end{array}$ & 27,375 & 28,35 & 0.965 \\
\hline D.C Box & 29,55 & 30,50 & 0.968 \\
\hline
\end{tabular}

\section{SIMPULAN}

Berdasarkan pengujian tekan yang telah dilakukan terhadap 3 jenis penampang baja ringan, beberapa hal yang dapat disimpulkan dari penelitian ini adalah penampang double channel box memiliki nilai kapasitas tekan dan kekakuan yang lebih besar yakni $63,18 \%$ dan 67\% jika dibandingkan dengan single channel, $7 \%$ dan $21,3 \%$ jika dibandingkan dengan double channel back to back. Selain itu, dikarenakan sampel baja ringan merupakan kolom pendek, tekuk lokal untuk 3 penampang tersebut terjadi saat beban ultimit tercapai.

Berdasarkan hasil beban ultimit yang didapatkan dari pengujian tekan dan dianalisis secara analitik dengan SNI 7971:2013, maka peraturan tersebut konservatif dalam menghitung kapasitas tekan baja ringan.

\section{UCAPAN TERIMAKASIH}

Penulis menyampaikan terima kasih pada LPPM Univ. Dharma Andalas atas bantuan dana melalui skim hibah penelitian dosen Universitas Dharma Andalas tahun 2018.

\section{DAFTAR PUSTAKA}

Badan Standarisasi Nasional Indonesia. 2013. "SNI 7971:2013 Standar Nasional Indonesia untukStruktur Baja Canai Dingin". Jakarta : Indonesia.

Kadir, A.M. 2013. "Investigasi Eksperimental Perilaku Profil Baja Ringan Berpenampang Persegi Akibat Interaksi Beban Tekan Memusat dan Momen Lentur". Jurnal Metalurgi Universitas Indonesia Vol 28 No 1 Hal 33-48 : Depok.

Sandjaya, Arif; dan Suryoatmono, B.2018. "Studi Eksperimental Batang Tekan Baja Canai Dingin Diperkaku Sebagian ". Jurnal Teknik Sipil Institut Teknologi Bandung Vol 25 No. 1.Hal 19-24 : Bandung.

Ruus, K . 2017. "Pengaruh Bentuk Profil Baja Ringan Terhadap Kuat Tekan". Jurnal Sipil Statik Vol 5 No. 5 Hal 249-262 : Manado.

Wen Wei, Yu. 2000. "Cold Formed Steel Design, Third Edition". University of Missoury-Rolla : United State of America (USA). 